\title{
Carotenoids, sugars, ascorbic acid, total phenolics, and antioxidant activity of murici from Brazilian Cerrado during refrigerated storage
}

\author{
Celso Martins Belisário ${ }^{*}$ (iD Antônio Gomes Soares $^{2}$ (D) \\ Regina Celi Cavestré Coneglian ${ }^{3}$ Geovana Rocha Plácido ${ }^{1}$ (D) \\ Carlos Frederico de Souza Castro ${ }^{4}$ Lamonier Antônio Nery Rodrigues ${ }^{1}$ (D)
}

${ }^{1}$ Programa de Pós-graduação em Tecnologia de Alimentos (PPGTA), Instituto Federal de Educação, Ciência e Tecnologia Goiano, $75901-970$ Rio Verde, GO, Brasil. E-mail: celso.belisario@ifgoiano.edu.br. *Corresponding author.

${ }^{2}$ Empresa Brasileira de Pesquisa Agropecuária (Embrapa), Agroindústria de Alimentos, Rio de Janeiro, RJ, Brasil.

${ }^{3}$ Programa de Pós-graduação em Fitotecnia (PPGF), Universidade Federal Rural do Rio de Janeiro (UFRRJ), Seropédica, RJ, Brasil.

${ }^{4}$ Programa de Pós-graduação em Agroquímica (PPGAq), Instituto Federal de Educação, Ciência e Tecnologia Goiano, Rio Verde, GO, Brasil.

ABSTRACT: Native fruits are economically important to small producers, and they are a important part of the diet of several communities. Therefore, postharvest studies of these fruits are essential. In addition, research involving their chemical composition can identify substances that add potential value to the fruits, especially from a nutritional and medicinal standpoint. This study characterized the fruits of the muricizeiro shrub (Byrsonima crassifolia, Malpighiaceae), which were harvested from native plants on private properties and stored for 16 days at a mean temperature of $12{ }^{\circ} \mathrm{C}$. The fruits were evaluated during storage for: 2,2-diphenyl-1-picrylhydrazyl (DPPH) radical scavenging activity, ascorbic acid content, phenolics and carotenoids total, carotenoids profile, glucose, fructose and sucrose contents. Overall, the temperature that the fruits were storage at was effective at maintaining the quality of the fruit. However, the ascorbic acid content of the fruits did decrease during the storage period. Results showed that the fruits had a high antioxidant capacity, possibly because of the presence of phenolic compounds and carotenoids. It is also important to highlight that this fruit is source of vitamin A, owing to the high concentration of $\beta$-carotene. Key words: postharvest, native fruits, Byrsonima crassifolia, Malpighiaceae, antioxidant activity.

Carotenoides, açúcares, ácido ascórbico, fenólicos totais e atividade antioxidante de murici do Cerrado brasileiro durante armazenamento refrigerado

RESUMO: Frutas nativas são economicamente importantes para pequenos produtores, e são uma parte importante da dieta de várias comunidades. Portanto, estudos pós-colheita desses frutos são essenciais. Além disso, pesquisas envolvendo sua composição química podem identificar substâncias que agregam valor potencial às frutas, principalmente do ponto de vista nutricional e medicinal. Este estudo caracterizou os frutos do arbusto muricizeiro (Byrsonima crassifolia, Malpighiaceae), que foram colhidos de plantas nativas em propriedades particulares e armazenados por 16 dias em temperatura média de $12{ }^{\circ} \mathrm{C}$. Os frutos foram avaliados durante o armazenamento em vista da: atividade de eliminação de radicais 2,2-difenil-1-picril-hidrazil (DPPH), conteúdo de ácido ascórbico, fenólicos e carotenoides totais, perfil de carotenoides, conteúdo de glicose, frutose e sacarose. No geral, a temperatura em que os frutos foram armazenados foi eficaz para manter a qualidade do fruto. No entanto, o teor de ácido ascórbico dos frutos diminuiu durante o periodo de armazenamento. Os resultados mostraram que os frutos apresentaram alta capacidade antioxidante, possivelmente pela presença de compostos fenólicos e carotenoides. Também é importante destacar que esta fruta é fonte de vitamina $A$, devido à alta concentração de $\beta$-caroteno.

Palavras-chave: pós-colheita, frutas nativas, B. crassifolia, Malpighiaceae, atividade antioxidante.

\section{INTRODUCTION}

The Brazilian Cerrado covers almost two million square kilometers of Brazil, and includes the states of Goiás, Tocantins, Mato Grosso do Sul, Minas Gerais, Bahia, Mato Grosso, Maranhão, and Piauí. It contains a rich variety in fruits, some of which have medicinal properties, high nutritional potential, and unique flavors. Despite their potential benefits, these fruits are little known to inhabitants of the large cities, instead, they are part of the customs and cultural activities of small communities, with processing limited to production of preserves, sweets, and ice cream (BRASIL, 2004; KLINK \& MACHADO, 2005).
One such fruit is the murici (Figure 1), which is produced by muricizeiro ( $B$. crassifolia, Malpighiaceae), a medium sized shrub (about $5 \mathrm{~m}$ high) that is native to the Cerrado region. The murici is a drupe fruit, with a globular or oblong shape, originating from a tricarpellary ovary, in which each carpel contains an egg. The diameter of the fruits ranges in size from 0.7 to $2.2 \mathrm{~cm}$, and they range in weight from 1 to $6 \mathrm{~g}$ (SOUZA \& LORENZI, 2008).

The murici fruit has a unique flavor, mainly owing to the presence of volatile esters (REZENDE \& FRAGA, 2003). It also has appreciated sensory attributes, including a sweetness that is a result of the sucrose, fructose, and glucose that are derived 


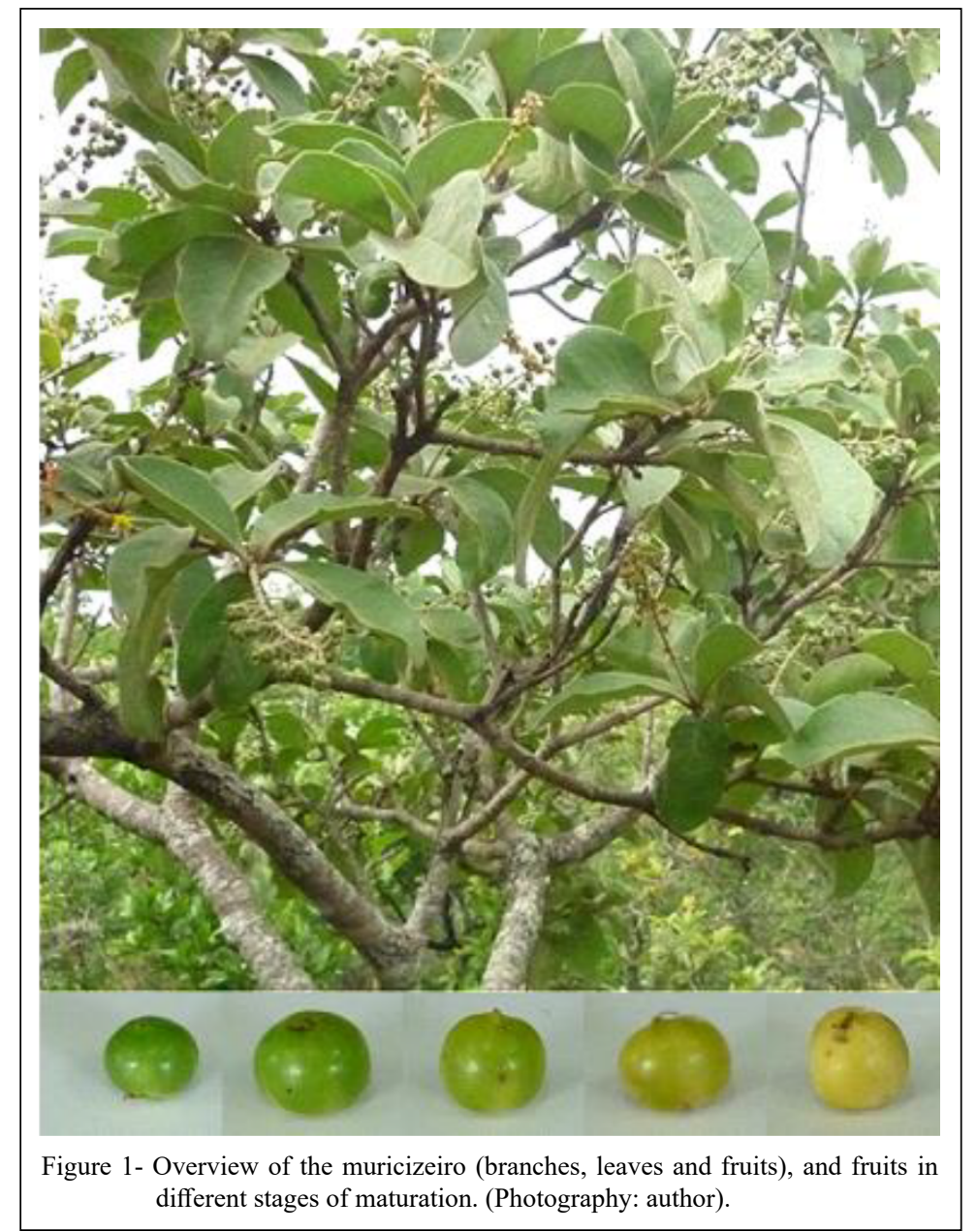

from the decomposition of polysaccharides (LIMA et al., 2011).

In addition to sensory characteristics, some research indicates a potential for medicinal use as well. According to ROCHA et al. (2013), studies on populations whose diets were based on native fruits, showed a correlation between the presence of high levels of bioactive compounds and a reduction in certain chronic diseases. These compounds include phenolics and other substances that can act as antioxidants.

SHAHIDI (1996), ROESLER et al. (2007), and ROCHA et al. (2013) studied the relationship between bioactive compounds with antioxidant activity and the reduction in certain chronic diseases. However, those studies do not explain how the preservation of these fruits may be improved so that the chemical, physical-chemical, and sensorial attributes of the fruit can be maintained during longer period of storage. This is important because several communities enjoy consuming fresh fruit. Therefore, the characterization of this fruit and its postharvest behavior will make important contributions to future studies that aim to promote the consumption of this fruit in an unprocessed state, and its potential for use in food related industries.

VIEIRA \& AGOSTINI-COSTA (2007) reported that carotenoids accumulate in various plant tissues. Their results showed that these pigments protect the fruit against photo-oxidation because they are associated with chemical and biochemical reactions that inhibit reactive oxygen species. Studies performed by MOLDOVAN et al. (2016) and MACEDO et al. (2017) reported that $\beta$-carotene: has high reactivity with electrophiles and oxidants, and inhibits the auto-oxidation of lipids in biological tissues and food products.

According to PERES et al. (2013), crude extracts of ethyl acetate from Murici-pequeno (Byrsonima intermedia) showed high antioxidant 
activity compared to other fruits from Cerrado. However, the flavonoid, quercetin, and rutin levels were low in $B$. intermedia fruit, indicating that the high antioxidant activity was due to the presence of other compounds.

SILVA \& ROGEZ (2013) verified that murici leaf extracts had higher total phenolic contents than the fruits they studied. In addition, a HPLC-DAD analysis identified and quantified three major phenolic compounds reported in murici: gallic acid, quercetin$3-\mathrm{O}-\alpha$-L-glycoside, and epigallocatechin gallate.

A study of the antioxidant activity in Byrsonima verbascifolia fruit pulp, using various methods (DPPH, ABTS, FRAP, and $\beta$-carotene/ linoleic acid), indicated that antioxidant activity was relatively low, but the results were dependent on the method used (MORAIS et al., 2013).

This study aimed to determine the profile and total carotenoid, sucrose, glucose, fructose, total phenolic, ascorbic acid, and antioxidant activity of murici when stored at a temperature of $12 \pm 1{ }^{\circ} \mathrm{C}$ during sixteen days.

\section{MATERIALS AND METHODS}

\section{Harvest and storage}

The murici (B. crassifolia, Malpighiaceae), were harvested in January, 2014, from existing plants at Poções Farm, located on the left bank of the GO469 highway, km 7, in Abadia de Goiás County, Goiás, Brazil (16 $48^{\prime} 07^{\prime \prime} \mathrm{S}$ and $49^{\circ} 26^{\prime} 10^{\prime \prime} \mathrm{W}, 872$ m.a.s.l).

The plants were selected according to visual characteristics: height, health, and juvenility. In total, three muricizeiro plants were selected, they had good juvenility characteristics, were approximately $2.5 \mathrm{~m}$ in height, and had a high fruit yield.

The fruit collection time was determined visually; the fruit were collected when they were pale green yellow in color and physiologically ripe. About 300 fruits were harvested, fruit was selected for uniform size and ripeness. The fruits were immediately sent to the Fruit and Vegetable Laboratory of the Goiano Federal Institute - Rio Verde Campus, where they were then stored in incubator Biochemical Oxygen Demand B.O.D. (Model Q-315 D Quimis ${ }^{\circledR}$ ) and maintained at a temperature of $12 \pm$ $1{ }^{\circ} \mathrm{C}$. The experiments were performed on the day of harvest and at 4, 8, 12, and 16 days after harvest.

\section{Ascorbic acid content}

An approximately $0.5 \mathrm{~g}$ sample was added to $50 \mathrm{ml}$ of aqueous solution in $1 \%$ metaphosphoric acid (Dinâmica ${ }^{\circledR}$ ). Then they were titrated with
2,6-dichlorophenol-indophenol-DCFI

(SigmaAldrich $^{\circledR}$ ), and $10 \mathrm{~mL}$ of a previously standardized solution of $10 \mathrm{mg} 100 \mathrm{~mL}^{-1}$ of L-ascorbic acid $\left(\right.$ Vetec $\left.^{\circledR}\right)$. Ascorbic acid contents were determined according to the Association of Official Analytical Chemists (AOAC) standards and expressed in $\mathrm{mg}$ $100 \mathrm{~g}^{-1}$ of pulp (OLIVEIRA et al., 2010).

\section{Phenolic total contents}

Approximately $2.5 \mathrm{~g}$ of murici pulp was added to a $15 \mathrm{~mL}$ aqueous-alcoholic solution $50 \%$ $(\mathrm{v} / \mathrm{v})$. The system was agitated for 24 hours, then filtrated, and finally supernatant was collected.

The reactive solution was prepared in a 10 $\mathrm{mL}$ volumetric flask: $5 \mathrm{~mL}$ of distilled water, $100 \mu \mathrm{L}$ of murici pulp extract, $0.5 \mathrm{~mL}$ of Folin-Ciocalteu reagent $\left(\right.$ Dinâmica $\left.^{\circledR}\right), 2 \mathrm{~mL}$ of sodium carbonate (Alphatec ${ }^{\circledR}$ ) at $15 \%(\mathrm{~m} / \mathrm{v})$, and then filled to $10 \mathrm{~mL}$ with distillated water. A calibration curve was performed, using the Gallic acid $\left(\right.$ Vetec $\left.^{\circledR}\right)$ standard, ranging from 0.035 to $0.28 \mathrm{mg} \mathrm{mL}^{-1}$. Absorbance readings were $765 \mathrm{\eta m}$ in Spectrophotometer UV/Vis (Model Lambda 750 Perkin Elmer $^{\mathbb{R}}$ ).

Total phenolic contents $\left(\mathrm{mg} \mathrm{g}^{-1}\right)$ were analyzed using the Folin-Cioalteu method, described by ROESLER et al. (2007) and SOUSA et al. (2007), and results were expressed as Gallic acid equivalents (GAE).

\section{Profile and total carotenoids}

It was used the method described by RODRIGUEZ-AMAYA (2001) to extract the carotenoids. Sample of approximately $3 \mathrm{~g}$ of murici pulp, including the peel, were macerated with acetone $\left(\right.$ Tedia $\left.^{\circledR}\right)$, then, filtered and fractionated with petroleum ether $\left(\right.$ Tedia $\left.^{\circledR}\right)$. To determine the total carotenoid content and the carotenoid profile $\left(\mu \mathrm{g} 100 \mathrm{~g}^{-1}\right)$, a high performance liquid chromatography (HPLC) was run in a Modular Liquid Chromatograph, with diode array detector (Model W600 - Waters ${ }^{\mathbb{R}}$ ), Chromatographic column $\mathrm{YMC}^{\circledR} \mathrm{C} 30$ Carotenoid (250 mm x $4.6 \mathrm{~mm}$; $3 \mu \mathrm{m})$ Waters $^{\circledR}$.

Standard solutions $(0.5,1.5,2.5,3.5$, 5.0, 6.5 and $8.0 \mu \mathrm{g} \mathrm{mL} \mathrm{m}^{-1}$ ) of lutein, zeaxanthin, $\beta$-cryptoxanthin, $\alpha$-carotene, $\beta$ - carotene, and 13 -cis$\beta$-carotene, were used to perform the calibration curve. The standards were extracted and purified from natural sources in the postharvest Laboratory at EMBRAPA (Empresa Brasileira de Pesquisa Agropecuária) Rio de Janeiro, RJ, Brazil. The carotenoids were quantified by injection of ethereal extracts from murici samples. Results were obtained under the same chromatographic conditions of the calibration curve. 
Chromatographic conditions: oven temperature $\left(33^{\circ} \mathrm{C}\right)$; mobile phase flow of $0.8 \mathrm{~mL}$ $\mathrm{min}^{-1}$; injection volume $(15 \mu \mathrm{L})$; analysis time $(28$ minutes); elution gradient with the mobile phases methanol and methyl tert-butyl ether $\left(\right.$ Tedia $\left.^{\circledR}\right)$.

\section{Sugar contents}

Sugar contents were determined according to MACRAE (1998). Approximately $1 \mathrm{~g}$ of sample and $10 \mathrm{~mL}$ of ultra-purified water (Milli- $\mathrm{Q}^{\circledR}$ ), were added to a $25 \mathrm{~mL}$ volumetric flasks, for each sample, followed by extraction in an ultrasonic bath for 20 minutes. Then $5 \mathrm{~mL}$ of acetonitrile $\left(\right.$ Tedia $^{\circledR}$ ) was added to each flask, finally, the flask was filled to the $25 \mathrm{~mL}$ mark with ultra-purified water. The filtrate was analyzed by HPLC using a refractive index detector. Chromatographic conditions: Chromatographic column (Amino $300 \mathrm{~mm}$ x 4.6 $\mathrm{mm}$, High performance Carbohydrate); column temperature $\left(25^{\circ} \mathrm{C}\right)$; mobile phases (acetonitrile); mobile phases flow of $1.4 \mathrm{~mL} \mathrm{~min}^{-1}$; detector internal temperature $\left(45{ }^{\circ} \mathrm{C}\right)$; injection volume $(20 \mu \mathrm{L})$; analysis time (20 $\mathrm{min})$.

\section{Antioxidant activity}

The method described by Rufino et al. (2007), was used to determine antioxidant activity. The $\mathrm{IC}_{50}$ values denoted the concentration of a sample required to scavenge $50 \%$ of the DPPH free radicals. Approximately $2.5 \mathrm{~g}$ of murici pulp was added in $40 \mathrm{~mL}$ of methanol $50 \%(\mathrm{v} / \mathrm{v})$, and after 60 minutes was centrifuged for 15 minutes, at 25.406,55 G (Model Universal 300 - Hettich ${ }^{\circledR}$ ). The supernatant was transferred to a $100 \mathrm{~mL}$ volumetric flask. The extraction process was repeated using acetone $70 \%$ ( $\mathrm{v} / \mathrm{v})$, the supernatants were added, and the volume was completed with distillate water.

Methanolic solutions (60, 50, 40, 30, 20 and $10 \mu \mathrm{M}$ ) of 2,2-diphenil-1-picrylhydrazyl (Sigma Aldrich $^{\circledR}$ ) were prepared and absorbance readings were taken at $515 \mathrm{\eta m}$ in a Spectrophotometer UV/ Vis, using methanol as blank. These absorbance readings were plotted against the concentrations, which resulted in a curve.

The following was added to a test tube for each extract: $100 \mu \mathrm{L}$ of extract and $3.9 \mathrm{~mL}$ of DPPH solution $60 \mu \mathrm{M}$. The test tubes were kept in a dark environment for 120 minutes and were run through the spectrophotometer under the same conditions as the standard curve. The control solution was $100 \mu \mathrm{L}$ of blend acetone $70 \%$ and methanol $50 \%$ with 3.9 $\mathrm{mL}$ of DPPH, and its absorbance was used in the determination of antioxidant activity.

\section{Statistical analysis}

The experimental design was completely randomized; all the analyses were performed in triplicate. The obtained data were submitted for analysis of variance (ANOVA), and the means were compared using the LSD test.

\section{RESULTS AND DISCUSSION}

There was a decrease in ascorbic acid content from the fourth to the eighth day of storage (Table 1), the mean value of this compound ranged

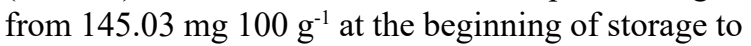

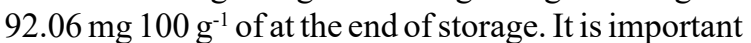
to note the values still remained high relative to other native Cerrado fruits including araticum $(34.0 \mathrm{mg}$ $\left.100 \mathrm{~g} \mathrm{~g}^{-1}\right)$, cagaita $\left(38.0 \mathrm{mg} 100 \mathrm{~g}^{-1}\right)$, gabiroba $(21.0 \mathrm{mg}$ $\left.100 \mathrm{~g}^{-1}\right)$, mangaba (26.1 $\left.\mathrm{mg} 100 \mathrm{~g}^{-1}\right)$ and pequi (10.0 $\mathrm{mg} 100 \mathrm{~g}^{-1}$ ), reported by SILVA et al. (2009).

Many factors affect the ascorbic acid content in the fruits after harvest, one of which is temperature. The total ascorbic acid content in fruits and vegetables includes both the non-hydrolyzed and hydrolyzed forms of ascorbic acid. The two forms showed vitamin activities and their contents can be used as a food quality index (CHITARRA \&

Table 1 - Ascorbic acid and total phenolic contents in the murici fruits stored at $12 \pm 1{ }^{\circ} \mathrm{C}$.

\begin{tabular}{lcc}
\hline Days after harvest & Ascorbic acid content $\left({\left.\mathrm{mg} 100 \mathrm{~g}^{-1}\right)}^{\mathrm{T}}\right.$ & Total phenolics (mg GAE $\mathrm{g}^{-1}$ sample) \\
\hline 0 & $145.03 \pm 1.38 \mathrm{a}$ & $165.2 \pm 0.43 \mathrm{a}$ \\
4 & $145.59 \pm 0.24 \mathrm{ab}$ & $157.9 \pm 0.21 \mathrm{ab}$ \\
8 & $111.25 \pm 3.53 \mathrm{~b}$ & $148.9 \pm 0.14 \mathrm{~b}$ \\
12 & $104.92 \pm 7.81 \mathrm{~b}$ & $143.4 \pm 1.08 \mathrm{bc}$ \\
16 & $92.06 \pm 7.80 \mathrm{~b}$ & $133.0 \pm 0.16 \mathrm{c}$ \\
$\mathrm{CV}(\%)$ & 5.94 & 3.59 \\
\hline
\end{tabular}

Mean value \pm standard deviation. Means with different letters in the same column are significantly different $(\mathrm{P}<0.05)$. 
CHITARRA, 2005). A decrease in the concentration of this compound during fruit ripening has also been reported in previous studies on climacteric fruits. The studies attributed this loss to either the degradation processes during ripening or temperature increases (LEE et al., 2000; MELO et al., 2000; CARNELOSSI et al., 2004).

Storing fruits and vegetables at temperatures close to $10{ }^{\circ} \mathrm{C}$ is one of the most efficient ways of reducing their metabolic rates, leading to a decrease in nutrient losses and an increase their shelf life (CHITARRA \& CHITARRA, 2005).

There was decrease in phenolic compound content during the fruit storage period (Table 1). The reduction in total phenolic concentrations was probably due to the ripening process. This was possibly owing to most of the phenolic compounds being present as acids, which become degraded as senescence progressed.

The phenolic concentrations reported in this study were close to those found in a study that evaluated methanolic extracts of the pulp and peel of the same fruit (PIZZA et al., 2011). In addition, a comparison between the amount of total phenols reported in this study with other fruits from the Cerrado showed that murici fruit contained more total phenols in the ethanolic extract than did araticum pulp (20.31 mg GAE $\mathrm{g}^{-1}$ ), cagaita pulp with peel

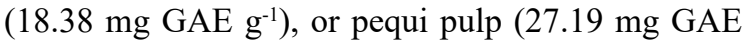
$\left.\mathrm{g}^{-1}\right)$ (ROESLER et al., 2007).

Table 2 shows the carotenoid profile and the total carotenoid concentration. $\beta$-cryptoxanthin $(1.5 \mu \mathrm{g} 100 \mathrm{~g}-1)$ and $\alpha$-carotene $\left(11.5 \mu \mathrm{g} 100 \mathrm{~g}^{-1}\right)$ were detected only on the day of harvest, possibly because they have low stability. It is important to highlight that murici was stored at $12{ }^{\circ} \mathrm{C}$ and after four days, losses of the most unstable compounds were expected. SILVA et al. (2016) evaluated the stability of bioactive compounds and antioxidant activity in fruits stored at $5{ }^{\circ} \mathrm{C}$ for 24 hours and determined that they had remained stable at that temperature.

$\beta$-carotene was found to be the carotenoid contributing the highest amount of vitamin A to this fruit. According to the IOM (2001), each $\mu$ g of retinol activity equivalent (RAE) corresponds to $12 \mu \mathrm{g}$ of $\beta$-carotene. The average amount of $\beta$-carotene in the murici fruit, stored in refrigeration, was $69.6 \mu \mathrm{g} 100$ $\mathrm{g}^{-1}$, which is equivalent to a vitamin A content of 5.8 $\mu \mathrm{g} 100 \mathrm{~g}^{-1}$ RAE. WONDRACEK et al. (2011) studied these compounds in passion fruit cultivars grown on the Cerrado and recorded values between 0.04 and $65.4 \mu \mathrm{g} 100 \mathrm{~g}^{-1}$ RAE.

The total carotenoid content varied during storage. There was an initial increase, followed by reduction in the intermediate periods of storage, and an increase at the end of the storage period. This behavior is similar to that observed by FONSECA et al. (2007), in the evolution of the pigments in papaya peel. Zeaxanthin; conversely, increased during storage, demonstrating an irregularity among the evolution of these compounds. This may have been due to the removal of samples from different fruits for each day of analysis, as this removal caused heterogeneity among the samples.

Carotenoids are also responsible for the antioxidant activity in foods. These activities can lead to the inhibition of several degenerative processes. Levels of these compounds reported in murici make it a promising functional and medicinal food (MOLDOVAN et al., 2016; MACEDO et al., 2017).

Glucose, fructose and sucrose contents (Table 3) increased from the $12^{\text {th }}$ to the $16^{\text {th }}$ day. According to CHITARRA \& CHITARRA (2005), sugar content increases with ripening. The sum of

Table 2 - Total carotenoids and carotenoid profile $\left(\mu \mathrm{g} 100 \mathrm{~g}^{-1}\right)$ of murici fruit stored at $12{ }^{\circ} \mathrm{C}$.

\begin{tabular}{|c|c|c|c|c|c|c|c|}
\hline DAH & $\begin{array}{c}\text { Total } \\
\text { carotenoids }\end{array}$ & Lutein & Zeaxanthin & $\begin{array}{c}\text { B - } \\
\text { cryptoxanthin }\end{array}$ & $\alpha$-carotene & $\beta$-carotene & $\begin{array}{l}13 \text { Cis } \beta \text { - } \\
\text { carotene }\end{array}$ \\
\hline 0 & $261.0 \pm 16.4 \mathrm{e}$ & $92.5 \pm 7.1 \mathrm{c}$ & $0.5 \pm 0.02 \mathrm{e}$ & $1.5 \pm 0.05$ & $11.5 \pm 0.5$ & $100.0 \pm 5.3 \mathrm{a}$ & $10.5 \pm 1.0 \mathrm{~b}$ \\
\hline 4 & $756.5 \pm 20.5 \mathrm{a}$ & $351.5 \pm 24.0 \mathrm{a}$ & $1.0 \pm 0.08 \mathrm{~d}$ & ND & ND & $100.0 \pm 7.4 \mathrm{a}$ & $13.5 \pm 1.0 \mathrm{a}$ \\
\hline 8 & $590.5 \pm 40.9 \mathrm{~b}$ & $338.0 \pm 30.0 \mathrm{a}$ & $7.0 \pm 0.5 \mathrm{c}$ & ND & ND & $51.0 \pm 3.1 \mathrm{c}$ & $7.5 \pm 0.3 \mathrm{~d}$ \\
\hline 12 & $422.0 \pm 33.5 \mathrm{~d}$ & $243.0 \pm 20.0 \mathrm{~b}$ & $11.5 \pm 1.2 \mathrm{~b}$ & ND & ND & $40.5 \pm 2.0 \mathrm{~d}$ & $6.0 \pm 0.2 \mathrm{e}$ \\
\hline 16 & $534.0 \pm 51.3 \mathrm{c}$ & $295.0 \pm 25.0 \mathrm{~b}$ & $23.0 \pm 1.0 \mathrm{a}$ & ND & ND & $56.5 \pm 3.5 \mathrm{~b}$ & $8.5 \pm 0.4 \mathrm{c}$ \\
\hline $\mathrm{CV}(\%)$ & 10.44 & 11.44 & 17.25 & - & - & 13.75 & 10.41 \\
\hline
\end{tabular}

DAH: days after harvest; ND: Not detected. Mean value \pm standard deviation. Means with different letters in the same column are significantly different $(\mathrm{P}<0.05)$. 
Table 3 - Fructose, Glucose and Sucrose contents and antioxidant activity of Murici fruits stored at $12 \pm 1{ }^{\circ} \mathrm{C}$.

\begin{tabular}{|c|c|c|c|c|}
\hline Days after harvest & 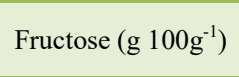 & 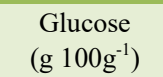 & 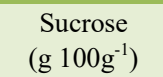 & Antioxidant activity $\mathrm{IC}_{50}\left(\mu \mathrm{g} \mathrm{mL}^{-1}\right)$ \\
\hline 0 & $1.48 \pm 0.035 \mathrm{~b}$ & $0.95 \pm 0.028 \mathrm{~b}$ & $0.24 \pm 0.014 \mathrm{~b}$ & $1.270 \pm 0.224 \mathrm{c}$ \\
\hline 4 & $1.84 \pm 0.028 \mathrm{~b}$ & $0.96 \pm 0.049 \mathrm{~b}$ & $0.37 \pm 0.049 \mathrm{~b}$ & $2.685 \pm 0.221 b$ \\
\hline 8 & $1.85 \pm 0.021 \mathrm{~b}$ & $1.00 \pm 0.007 \mathrm{~b}$ & $0.41 \pm 0.014 \mathrm{~b}$ & $2.688 \pm 0.221 b$ \\
\hline 12 & $1.94 \pm 0.035 \mathrm{~b}$ & $1.00 \pm 0.049 \mathrm{~b}$ & $0.42 \pm 0.077 \mathrm{~b}$ & $2.973 \pm 0.220 \mathrm{a}$ \\
\hline 16 & $2.38 \pm 0.028 \mathrm{a}$ & $1.44 \pm 0.007 \mathrm{a}$ & $0.74 \pm 0.014 \mathrm{a}$ & $2.945 \pm 0.219 \mathrm{a}$ \\
\hline $\mathrm{CV}(\%)$ & 1.70 & 0.70 & 6.21 & 3.27 \\
\hline
\end{tabular}

Mean value \pm standard deviation. Means with different letters are significantly different $(\mathrm{P}<0.05)$.

the glucose, fructose, and sucrose averages, that is, the total sugar content of the fruit, was around $3.9 \mathrm{~g}$ $100 \mathrm{~g}^{-1}$, which was low compared to other fruits. For example, the total sugar content reported in jabuticaba

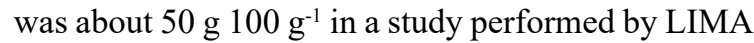
et al. (2011). These low total sugar values were expected owing mainly to the presence of volatile esters reported in most of fruits native from the Cerrado (REZENDE \& FRAGA, 2003).

The antioxidant activity (AA) (Table 3) decreased over the storage period. The minimum values were recorded on days 12 and 16 of storage. The antioxidant potentials were greater than those calculated for the ethanolic and aqueous extracts from different fruits native to the Cerrado (e.g., pequi had an $\mathrm{IC}_{50}=9.34 \mu \mathrm{g} \mathrm{mL}^{-1}$ (ROESLER et al., 2007).

\section{CONCLUSION}

Ascorbic acid levels remained high throughout the storage period. Although, total phenolic concentrations decreased during storage, they were still higher than those reported in other fruits from the Cerrado that have already been characterized. The murici fruit had low sugar concentrations. Murici fruits have large amounts of carotenoids, which may contribute to their high antioxidant potential. In addition, the $\beta$-carotene content suggests that they may be a good source of vitamin A. The antioxidant activity remained high during the storage period, which means that it is a promising functional and medicinal food. Temperature used for storage was low enough to maintain the nutritional quality and chemical composition of the fruits.

\section{ACKNOWLEDGMENTS}

The authors would like to thank Coordenação de Aperfeiçoamento de Pessoal de Nível Superior (CAPES), Brasil, research funding agency for the scholarships granted to the corresponding author - EDITAL Nº4/2009 MINTER/DINTER CAPES-SETEC. We also thank the D.Sc. Sidney Pacheco (EMBRAPA) for running the sugars and carotenoids analysis.

\section{DECLARATION OF CONFLICT OF INTERESTS}

The authors declare no conflict of interest. The founding sponsors had no role in the design of the study; in the collection, analyses, or interpretation of data; in the writing of the manuscript, and in the decision to publish the results.

\section{AUTHORS' CONTRIBUTIONS}

All authors contributed equally for the conception and writing of the manuscript. All authors critically revised the manuscript and approved of the final version.

\section{REFERENCES}

BRASIL. Ministério do Meio Ambiente Programa nacional de conservação e uso sustentável do bioma cerrado. Brasília-DF, 2004. Available from: <http://www.mma.gov.br/estruturas/201/ arquivos/programa_cerrado_sustentvel_201.pdf $>$. Accessed: Feb. $18,2014$.

CARNELOSSI, M.A.G et al. Conservação pós-colheita de mangaba (Hancornia speciosa Gomes). Ciência e Agrotecnologia, v. 28, p.1119-1125, 2004. Available from: <http://dx.doi.org/10.1590/ S1413-70542004000500021>. Accessed: Feb. 18, 2014. doi: 10.1590/S1413-70542004000500021.

CHITARRA, M.I.F; CHITARRA, A.B. Pós-colheita de frutas e hortaliças: fisiologia e manuseio. $2^{\text {a }}$ ed. Lavras: Esal/Faepe, 2005. 785p. 
FONSECA, M.J.O. et al. Evolução dos pigmentos durante o amadurecimento de mamão 'Sunrise Solo' e 'Golden'. Revista Brasileira de Fruticultura, v.29, n.3, p.451-455, 2007. Available from: <https://dx.doi.org/10.1590/S0100-29452007000300009>. Accessed:Feb. 18, 2014. doi: 10.1590/S0100-29452007000300009.

IOM - Institute of Medicine Food and Nutrition Board. Dietary reference intakes for vitamin $\mathrm{A}$, vitamin $\mathrm{K}$, arsenic, boron, chromium, copper, iodine, iron, manganese, molybdenum, nickel, silicone, vanadium, and zinc. Washington: National Academy Press, 2001. 773p. Available from: <https://www.ncbi.nlm.nih gov/books/NBK222310/>. Accessed: Feb. 18, 2014

KLINK, C.A.; MACHADO, R.B. Conservation of the Brazilian Cerrado. Conservation Biology, v. 42, p.707-713. Available from: $<$ http://dx.doi.org/10.111/j.1739.2005.00702.x>. Accessed: Feb 18, 2014. doi: 10.111/j.1739.2005.00702.x

LEE S.K.; KADER, A.A. Preharvest and postharvest factors influencing vitamin $\mathrm{C}$ content of horticultural crops. Postharvest Biology and Technology, v.20, p.207-220, 2000. Available from: $<$ http://dx.doi.org/10.1016/S0925-5214(00)00133-2>. Accessed: Feb. 18, 2014. doi: 10.1016/S0925-5214(00)00133-2.

LIMA, A. de J.B. et al. Sugars, organic acids, minerals and lipids in jabuticaba. Revista Brasileira de Fruticultura, Jaboticabal, v.33, n.2, p.540-550, 2011. Available from: <http://dx.doi. org/10.1590/S0100-29452011000200026>. Accessed: Feb. 18, 2014. doi: 10.1590/S0100-29452011000200026.

MACEDO, I.Y.L. et al. Electroanalytical tools for antioxidant evaluation of red fruits dry extracts. Food Chemistry, v.217, p.326-331, 2017. Available from: <https://www.ncbi.nlm.nih.gov/ pubmed/27664641>. Accessed: May, 20, 2018. doi: 10.1016/j. foodchem.2016.08.082.

MACRAE, R. Food Science and technology - A series of monographs. In HPLC in food analysis. $2^{\mathrm{a}} \mathrm{ed}$. Editora Academic Press, 1998. 77p.

MELO, E.A. et al. Temperatura no armazenamento de pitanga. Scientia Agricola, v.57, p.629-634, 2000. Available from: <http:// dx.doi.org/10.1590/S0103-90162000000400006>. Accessed: Feb. 18, 2014. doi: 10.1590/S0103-90162000000400006.

MOLDOVAN, B. et al. Antioxidant activity of Cornelian cherry (Cornus mas L.) fruits extract and the in vivo evaluation of its antiinflammatory effects. Journal of Functional Foods, v.26, p. 77-87, 2016. Avalilable from: <https://doi.org/10.1016/j.jff.2016.07.004>. Accessed: May, 20, 2018. doi: 10.1016/j.jff.2016.07.004.

MORAIS, M.L. et al. Determinação do potencial antioxidante in vitro de frutos do Cerrado brasileiro. Revista Brasileira de Fruticultura, v.35, p.355-360, 2013. Available from: <http:// dx.doi.org/10.1590/S0100-29452013000200004>. Accessed: Feb. 18, 2014. doi: 10.1590/S0100-29452013000200004

OLIVEIRA, R.G. et al. Otimização de metodologia colorimétrica para a determinação de ácido ascórbico em geleias de frutas. Ciência e Tecnologia de alimentos, v.30, p.244-249, 2010. Available from: <http://dx.doi.org/10.1590/S010120612010000100036>. Accessed: Feb. 18, 2014. doi: 10.1590 S0101-20612010000100036.

PERES, M.T.L.P. et al. Phytotoxic and antioxidant activity of seven native fruits of Brazil. Acta Botanica Brasilica, v.27, p.836-846, 2013. Available from: <http://dx.doi.org/10.1590/ S0102-33062013000400024>. Accessed: Feb. 18, 2014. doi: $10.1590 / \mathrm{S} 0102-33062013000400024$

PIZZA, C. et al. Phenolic compounds from Byrsonima crassifolia L. bark: Phytochemical investigation and quantitative analysis by LC-ESI MS/MS. Journal of Pharmaceutical and Biomedical Analysis, v. 56, p.1-6, 2011.

Available from: $<$ https://doi.org/10.1016/j.jpba.2011.03.032>. Accessed: Feb. 18, 2014. doi: 10.1016/j.jpba.2011.03.032.

REZENDE, C.M.; FRAGA, S.R. Chemical and aroma determination of the pulp and seeds of murici (Byrsonima crassifolia L.) Journal Brazilian Chemistry Society, São Paulo, v.14, n. 3, p.425-428, 2003. Available from: <http://dx.doi. org/10.1590/S0103-50532003000300014>. Accessed: Feb. 18, 2014. doi: 10.1590/S0103-50532003000300014.

ROCHA, M.S. et al. Caracterização físico-química e atividade antioxidante (in vitro) de frutos do cerrado piauiense. Revista Brasileira de Fruticultura, v.35, p.933-941, 2013. Available from: <http://dx.doi.org/10.1590/S0100-29452013000400003>. Accessed: Feb. 18, 2014. doi: 10.1590/S0100-29452013000400003.

RODRIGUEZ-AMAYA, D.B. A Guide To Carotenoid Analysis In Foods. Washington: Ilsi, 2001. 64p. Available from: <http:// beauty-review.nl/wp-content/uploads/2014/11/A-guide-tocarotenoid-analysis-in-foods.pdf $>$. Accessed: Feb. 18, 2014.

ROESLER, R. et al. Atividade antioxidante de frutas do Cerrado. Ciência e Tecnologia de Alimentos, v.27, p.53-60, 2007. Available from: <http://dx.doi.org/10.1590/S010120612007000100010>. Accessed: May, 20, 2016. doi: 10.1590/ S0101-20612007000100010.

RUFINO, M. do S.M. et al. Metodologia Científica: Determinação Da Atividade Antioxidante Total Em Frutas Pela Captura Do Radical Livre DPPH. Comunicado Técnico 127, Embrapa Agroindústria Tropical, 2007.

SHAHIDI, F. Natural antioxidants: an overview. In Natural Antioxidants Chemistry, Health Effects, and Applications. Champaign: AOCS Press, 1996. 318p.

SILVA, A.M.L. et al. Avaliação do teor de ácido ascórbico em frutos do cerrado durante o amadurecimento e congelamento. Estudos, v.36, n.6, p.1159-1169, 2009. Available from: <http:// dx.doi.org/10.18224/est.v36i6.484.g825>. Accessed: Mar. 29, 2019. doi: 10.18224/est.v36i6.484.g825.

SILVA, B.P. et al. Avaliação da estabilidade da capacidade antioxidante e de parâmetros físico-químicos de néctares de frutas caseiros. Revista Instituto Adolf Lutz, v.75, p.1-10, 2016. Available from: <https://www.bvs-vet.org.br/vetindex/ periodicos/revista-do-instituto-adolfo-lutz/75-(2016)/>. Accessed: Mar. 29, 2019

SILVA, J.J.M.; ROGEZ, H. Avaliação da estabilidade oxidativa do óleo bruto de açaí (Euterpe oleracea) na presença de compostos fenólicos puros ou de extratos vegetais amazônicos. Química Nova, v.36, p.400-406, 2013. Available from: <http://dx.doi. org/10.1590/S0100-40422013000300009>. Accessed: Feb. 18, 2014. doi: 10.1590/S0100-40422013000300009.

SOUSA, C.M. de M. et al. Fenóis totais e atividade antioxidante de cinco plantas medicinais. Química Nova, v.30, p.351-355, 
2007. Available from: <http://dx.doi.org/10.1590/S010040422007000200021>. Accessed: Feb. 18, 2014. doi: 10.1590/ S0100-40422007000200021.

SOUZA, V.C.; LORENZI, H. Botânica E Sistemática: Guia Ilustrado Para Identificação Das Famílias De Fanerógamas Nativas E Exóticas No Brasil Baseado Em APG II. 2 ${ }^{\mathrm{a}}$ ed., Nova Odessa, SP: Instituto Plantarum, 2008. 704p.

VIEIRA, R.F.; AGOSTINI-COSTA, T.S. Caracterização química de metabólitos secundários em germoplasma vegetal. In: NASS, L.L.
Recursos Genéticos Vegetais. Brasília: Embrapa Recursos Genéticos e Biotecnologia, 2007. p.343-372. Available from: <https://www. embrapa.br/documents/1355163/2005846/doc315.pdf/501dcbced5bb-4a10-c91-67e786b4b9db>. Accessed: Feb. 18, 2014.

WONDRACEK, D.C. et al. Composição de carotenoides em passifloras do Cerrado. Revista Brasileira de Fruticultura, v.33, n.4, p.1222-1228, 2011. Available from: <http://dx.doi. org/10.1590/S0100-29452011000400022>. Accessed: May, 20, 2016. doi: 10.1590/S0100-29452011000400022. 